\title{
POLA KONSUMSI PANGAN DAN ASUPAN ENERGI DAN ZAT GIZI ANAK STUNTING DAN TIDAK STUNTING 0-23 BULAN
}

\author{
(Food and nutrients intake of stunting and non-stunting young children 0-23 months)
}

\author{
Aslis Wirda Hayati ${ }^{*}$, Hardinsyah² ${ }^{2}$ Fasli Jalal ${ }^{3}$, Siti Madanijah², dan Dodik Briawan² \\ 1Jurusan Gizi, Politeknik Kesehatan Kemenkes Pontianak, Pontianak, \\ 2Departemen Gizi Masyarakat FEMA-IPB, \\ ${ }^{3}$ Fakultas Kedokteran, Universitas Andalas, Padang
}

\begin{abstract}
The objectives of this study were to analyze food consumption, energy, and nutrients intake patterns between stunting and non-stunting in young children of 0-23 months old, using the data from BHR (Basic Health Research) 2010. The data sub-set from BHR 2010 was obtained into e-files form. From 6634 under-two children 3539 were screened out due to incompleteness, outlier, and unusual food consumption during data collection. Nutritional status data were processed using the WHO AnthroPlus 2007, while the other datal statistics were processed using the Excel and SPSS for windows. The different on food consumption pattern was performed with Man-Whitney $U$ test. Food consumption, energy and nutrients intake patterns which measured were type number of food consumption, group number of food consumption, frequency of food consumption, nutrient adequacy, nutrient quality, and nutrients density. The results of study showed that analyze food consumption, and energy and nutrients intake patterns were different between stunting and non-stunting YC according to their age group; the higher the age, the higher their difference. There was no difference in food consumption, and energy and nutrients intake patterns between stunting and non-stunting children 0-5 months. Meanwhile, there was difference in children 6-11 and 12-23 months. The average of protein adequacy and protein density was difference between stunting and non-stunting children 6-11 months. In children 12-23 months, the differences not only in the average of protein adequacy and protein density but also in average of energy and calcium adequacy and calcium density, phosphor, vitamin $A$, and $C$ adequacy, nutrient quality, and type number of food. Implications for Indonesia that is necessary to study the efficacy of nutritional interventions to achieving optimal linear growth in young children.
\end{abstract}

Key words: children 0-23 months old, food pattern, stunting

\begin{abstract}
ABSTRAK
Penelitian ini bertujuan menganalisis pola konsumsi pangan dan asupan energi dan gizi anak stunting dan tidak stunting 0-23 bulan menggunakan data Riskesdas 2010. Sub-set data Riskesdas 2010 diperoleh dalam bentuk e-files. Dari 6634 data anak baduta dalam e-files Riskesdas 2010, sejumlah 3539 data anak dikeluarkan karena data tidak lengkap, pencilan, konsumsi pangan saat kondisi tidak biasa. Status gizi diolah menggunakan WHO AntroPlus 2007, pengolahan data lainnya menggunakan program Microsoft Excel 2007 dan SPSS for windows. Uji beda pola konsumsi pangan menerapkan Mann-Whitney $U$ test. Pola konsumsi pangan dan asupan energi dan zat gizi yang diukur berupa jumlah jenis konsumsi pangan, jumlah kelompok konsumsi pangan, frekuensi konsumsi pangan, tingkat kecukupan zat gizi, mutu gizi asupan pangan, dan densitas asupan zat gizi. Hasil kajian menunjukkan pola konsumsi pangan dan asupan energi dan zat gizi anak stunting dan tidak stunting 0-23 bulan berbeda menurut kelompok umur; semakin bertambah umur semakin meningkat perbedaannya. Pada anak 0-5 bulan tidak ada perbedaan pola konsumsi pangan dan asupan energi dan gizi anak stunting dan tidak stunting; sebaliknya pada anak 6-11 dan 12-23 bulan. Pada anak 6-11 bulan, rata-rata tingkat kecukupan protein anak stunting dan tidak stunting berbeda, demikian pula densitas asupan protein. Pada anak 12-23 bulan, tidak hanya rata-rata tingkat kecukupan protein dan densitas asupan protein, tetapi ratarata tingkat kecukupan energi, tingkat kecukupan kalsium dan densitas asupan kalsium, tingkat kecukupan fosfor, tingkat kecukupan vitamin A, tingkat kecukupan vitamin C, mutu gizi makanan, dan bahkan jenis pangan juga berbeda. Implikasi untuk Indonesia yaitu perlu dilakukan penelitian efikasi intervensi zat gizi tersebut untuk pencapaian pertumbuhan linier optimal anak.
\end{abstract}

Kata kunci: anak 0-23 bulan, pola konsumsi pangan, stunting

"Korespondensi: Jurusan Gizi, Politeknik Kesehatan Kemenkes Pontianak, Jl. 28 Oktober Siantan Hulu, Pontianak 78124. Telp. 0561-883979; Fax: 0561-883765; Email: asliswirda@yahoo.com 
Hayati dkk.

\section{PENDAHULUAN}

Masalah stunting akhir-akhir ini semakin menjadi perhatian terutama di negara-negara sedang berkembang termasuk Indonesia. Hasil studi Riskesdas di Indonesia oleh Kemenkes (2010) menemukan prevalensi stunting anak 1 dan 2 tahun berturutturut sebanyak 32.1 dan $41.5 \%$, dan studi review di 36 negara oleh Bhutta et al. (2008) menemukan sebanyak 40 dan 54\%. WHO (2006) menjelaskan bahwa prevalensi stunting yang lebih besar dari 20\% dianggap tinggi dan merupakan suatu masalah kesehatan masyarakat.

Temuan mutakhir yang berhubungan dengan stunting antara lain oleh Bhutta et al. (2008) menyimpulkan bahwa Makanan Pendamping Air Susu Ibu (MP-ASI) yang difortifikasi dapat meningkatkan panjang badan anak, namun peningkatan tersebut sangat kecil. Beberapa penelitian anak stunting di Indonesia yaitu oleh Kusharisupeni (2006) di Kabupaten Indramayu, Ulfani et al. (2011) di Indonesia menyimpulkan keterkaitan stunting dengan faktor non-gizi. Sementara itu, Kemenkes (2010) melaporkan bahwa data konsumsi pangan anak 0-23 bulan Riset Kesehatan Dasar (Riskesdas) Nasional 2010 tidak dianalisis karena pada umur tersebut bayi atau anak masih mengonsumsi Air Susu Ibu (ASI) sedangkan konsumsi energi dan zat gizi makro dari ASI sulit diperhitungkan.

Indonesia memerlukan informasi pola konsumsi pangan dan asupan energi dan zat gizi anak stunting dan tidak stunting dari kajian faktor gizi di Indonesia sebagai salah satu upaya mengatasi masalah stunting. Sehubungan hal tersebut, tujuan penelitian ini menganalisis pola konsumsi pangan dan asupan energi dan zat gizi anak stunting dan tidak stunting 0-23 bulan di Indonesia.

\section{METODE}

\section{Desain, Waktu, dan Tempat}

Data Riskesdas 2010 yang dilaksanakan oleh Balitbangkes, Kemenkes digunakan dalam penelitian ini. Desain Riskesdas 2010 adalah potong lintang dan merupakan penelitian non-intervensi. Pengumpulan data dilakukan bulan Mei hingga Agustus 2010. Penelitian dilakukan pada bulan Maret-Nopember 2012.

\section{Jumlah dan Cara Pengambilan Data}

Subjek Riskesdas 2010 mewakili seluruh rumah tangga di Indonesia. Pemilihan subjek dilakukan secara acak dalam dua tahap. Tahap pertama dilakukan pemilihan Blok Sensus (BS) dan tahap kedua pemilihan rumah tangga, yaitu sejumlah 25 rumah tangga setiap BS. Besar subjek yang direncanakan sebanyak 2800 BS. Subjek BS tersebut tersebar di 33 provinsi dan 441 kabupaten/kota. Data yang berhasil dikumpulkan sebanyak sejumlah 2798 BS subjek (99.9\%) dari 2800 BS subjek yang direncanakan. Pengumpulan dan entri data dilakukan tenaga kesehatan terlatih (minimal tamat D3 kesehatan). Pemeriksaan kelengkapan dan kebenaran data dilakukan oleh Penanggung Jawab Teknis Kabupaten/ Kota, kemudian data dikirim secara elektronik kepada tim manajemen data di Balitbangkes.

Peneliti memperoleh sub-set data Riskesdas 2010 dalam bentuk e-files. Dari 6634 data anak baduta dalam e-files tersebut, sejumlah 3539 data anak dikeluarkan karena data berat badan dan panjang badan anak tidak lengkap (644 orang), nilai z-skor BB/U, PB/U dan IMT/U termasuk pencilan berdasarkan Blössner et al. (2009) yaitu -6<BB/U>5; $-6<\mathrm{PB} / \mathrm{U}>6$; -5<BMI/U>5 (447 orang), pengumpulan data asupan pangan saat kondisi tidak biasa yaitu hajatan/hari besar/sakit (46 orang), dan nilai asupan energi termasuk pencilan berdasarkan Amilia (2011) yaitu asupan energi <0.3 BMR atau >3.0 BMR (2 402 orang).

\section{Jenis dan Cara Pengumpulan Data}

Data Riskesdas 2010 meliputi keterangan rumah tangga dan keterangan anggota rumah tangga. Keterangan rumah tangga meliputi identitas, fasilitas pelayanan kesehatan, sanitasi lingkungan, dan pengeluaran. Keterangan individu antara lain meliputi identitas individu, kesehatan anak, dan konsumsi makanan dalam 24 jam terakhir. Pengukuran tinggi badan/panjang badan dan berat badan dilakukan pada setiap subjek.

Pola konsumsi pangan dan asupan energi dan zat gizi yang diukur berupa: jumlah jenis, jumlah kelompok, dan frekuensi konsumsi pangan, tingkat kecukupan energi, tingkat kecukupan protein, tingkat kecukupan kalsium, tingkat kecukupan fosfor, tingkat kecukupan zat besi, tingkat kecukupan vitamin $A$, tingkat kecukupan vitamin B1, tingkat kecukupan vitamin C, mutu gizi makanan, densitas asupan protein, densitas asupan kalsium, densitas asupan zat besi, densitas asupan vitamin A, densitas asupan vitamin B1, dan densitas asupan vitamin C.

\section{Pengolahan dan Analisis Data}

Nilai z-skor PB/U anak memperhatikan posisi pengukuran, apabila diukur dalam posisi anak berdiri, maka $\mathrm{PB}=\mathrm{TB}+0.7 \mathrm{~cm}$ (Blössner et al. 2009). Anak disebut stunting apabila z-skor $\mathrm{PB} / \mathrm{U}<-2 \mathrm{SD}$ dan tidak stunting apabila z-skor PB/U $\geq-2$ SD (Jahari 2009).

Data konsumsi pangan individu dikumpulkan dengan metode kuantitatif 24-hour recall. Berat ASI yang dikonsumsi anak menggunakan faktor konversi dari hasil studi pendahuluan (weighing method) dan analisis mendalam data konsumsi ASI Riskesdas 2010 yaitu bahwa 1 kali minum (1 kali masa mengisap ASI) $=50 \mathrm{~g}=5$ menit=0.5 botol susu (dot) sedang=0.5 gelas kecil. 
Energi yang dibutuhkan anak usia 0-23 bulan dihitung berdasarkan rumus perhitungan kebutuhan energi Mahan dan Escott-Stump (2008).

Kebutuhan energi $(\mathrm{kkal})=\mathrm{EER}+10 \%$ TEE

Tabel 1. Perhitungan Estimasi Kebutuhan Energi (EER) menurut Umur

\begin{tabular}{cc}
\hline Umur (bulan) & Formula EER \\
\hline $0-3$ & $89 \times \mathrm{BB}-100+175 \mathrm{kkal}^{*}$ \\
$4-6$ & $89 \times \mathrm{BB}-100+56 \mathrm{kkal}^{*}$ \\
$7-12$ & $89 \times \mathrm{BB}-100+22 \mathrm{kkal}^{*}$ \\
$13-23$ & $89 \times \mathrm{BB}-100+20 \mathrm{kkal}^{*}$ \\
\hline
\end{tabular}

Keterangan:

EER $=$ estimasi kebutuhan energi

TEE $=$ total pengeluaran energi $($ TEE $=89 \times$ Berat Badan-100 $)$

$\mathrm{EER}=\mathrm{TEE}+$ Energy deposit $^{(*)}$

Energi yang dibutuhkan anak dihitung sesuai dengan usia dan berat badan aktual berdasarkan Total Energy Expenditure (TEE) yang dikoreksi dengan Thermic Effect of Food (TEF). TEF merupakan peningkatan pengeluaran energi yang berhubungan dengan asupan pangan. Besarnya nilai TEF dihitung dari total pengeluaran energi yaitu sebesar $10 \%$ dari TEE. Perhitungan kebutuhan energi pada anak juga termasuk kebutuhan Energy Deposit yang merupakan kalori tambahan untuk mendukung deposisi jaringan yang dibutuhkan untuk pertumbuhan bayi dan anak.

Status gizi anak perlu diketahui melalui IMT/U (Blössner et al. 2009). Klasifikasi status gizi berdasarkan z-skor IMT/U yaitu: sangat kurus jika IMT/ $\mathrm{U}<-3 S D$, kurus jika $-3 S D \geq I M T / U<-2 S D$, normal jika $-2 S D \geq I M T / U<-2 S D$, gemuk jika $2 S D \geq I M T / U<3 S D$, dan obes jika IMT/U>3SD. BB normal anak yang status gizinya tidak normal digunakan median BB menurut umur dan jenis kelamin.

Kebutuhan protein anak dihitung berdasarkan pada formula Angka Kecukupan Protein (AKP) dalam WNPG (2004) sesuai dengan kelompok umur yaitu: 0-6, 7-11, dan 12-23 bulan masing-masing berturut-turut $10 \mathrm{~g}$ (AKP dikoreksi mutu), $1.5 \mathrm{~g} / \mathrm{kg} \mathrm{BB} /$ hari $x 1.2$, dan $1.2 \mathrm{~g} / \mathrm{kg} \mathrm{BB} /$ hari $\times 1.2$. Perhitungan kebutuhan protein disesuaikan dengan berat badan aktual subjek, serta dikoreksi dengan faktor koreksi mutu protein sebesar 1.2. Faktor koreksi mutu tersebut didasarkan pada rendahnya mutu protein makanan penduduk Indonesia.

Kebutuhan $\mathrm{Ca}, \mathrm{P}, \mathrm{Fe}$, vitamin A, vitamin B1, dan vitamin $C$ dihitung berdasarkan Angka Kecukupan Gizi (AKG) sesuai umur (WNPG 2004). Berdasarkan data asupan zat gizi anak, diperoleh data tingkat kecukupan zat gizi yaitu asupan zat gizi dibagi angka kecukupan gizi yang dianjurkan kemudian hasilnya dikali $100 \%$.

Mutu gizi asupan pangan (MGP) dihitung dengan menjumlahkan tingkat kecukupan masingmasing zat gizi (truncated at 100) kemudian dibagi dengan jumlah zat gizi yang dipertimbangkan dalam penilaian MGP (Hardinsyah 2001). Adapun densitas asupan zat gizi (DG) dihitung berdasarkan asupan zat gizi dibagi asupan energi (kkal) kemudian dikali 1000 kkal (Drewnowski 2005).

Perangkat lunak WHO AnthroPlus 2007 digunakan untuk mengolah status gizi, pengolahan data lainnya menggunakan program Microsoft Excel 2007 dan SPSS 16.0 for windows. Analisis pola konsumsi pangan dan asupan energi dan gizi gizi menerapkan Uji Mann-Whitney $U$.

\section{HASIL DAN PEMBAHASAN}

Sebanyak 37.4\% anak 0-23 bulan menderita stunting. Seiring dengan bertambahnya umur anak, prevalensi stunting juga bertambah. Pada 0-5, 6-11, dan 12-23 bulan, prevalensi stunting masingmasing berturut-turut sebanyak 24.5\%, 32.8\%, dan $40.2 \%$. Prevalensi stunting tersebut hampir sama dengan yang dilaporkan Kemenkes (2010) yaitu: 28.1\%, 32.1\%, dan 41.5\%. Prevalensi stunting anak perempuan hampir sama dengan anak laki-laki yaitu $35.9 \%$ dan $38.7 \%$.

\section{Jenis dan Kelompok Pangan}

Rata-rata jumlah jenis pangan yang dikonsumsi anak stunting 0-5 dan 6-11 bulan sama dengan anak tidak stunting; namun pada anak 12-23 bulan berbeda $(p<0.05)$. Rata-rata jumlah jenis pangan yang dikonsumsi anak stunting dan anak tidak stunting $12-23$ bulan berturut turut yaitu $4.4 \pm 1.9$ dan 4.6 \pm 2.0 jenis pangan per hari (Tabel 2 ).

Bertambah usia bertambah pula jumlah jenis pangan yang dikonsumsi anak 0-23 bulan. Rata-rata jumlah jenis pangan yang dikonsumsi anak 0-5, 6-11, dan 12-23 bulan berturut-turut yaitu 1.3 \pm 0.6 , $3.2 \pm 1.5$, dan $4.6 \pm 2.0$ jenis per hari.

Total jenis pangan yang dikonsumsi anak 0-23 bulan yaitu 1 sampai dengan 13 jenis pangan per hari. Hampir empat per lima anak 0-23 bulan mengonsumsi dua sampai dengan enam jenis pangan per hari. Sisanya, mereka mengonsumsi satu atau lebih dari enam jenis pangan per hari (Tabel 3 ).

Anak stunting dan anak tidak stunting 0-23 bulan mengonsumsi sekitar seperempat jenis pangan yang tercantum di Daftar Komposisi Bahan Makanan (DKBM) Indonesia. Jumlah jenis pangan yang ada di dalam DKBM Indonesia sebanyak 654 jenis (Hardinsyah \& Briawan 1994). Dengan demikian anak stunting dan tidak stunting 0-23 bulan telah mengonsumsi berturut-turut $24.6 \%$ dan $28.9 \%$ total jenis pangan yang ada di DKBM tersebut. Pangan yang mereka konsumsi dikelompokkan menjadi dela- 
Tabel 2. Pola Konsumsi, Asupan Energi, dan Zat Gizi Harian Anak 0-23 Bulan berdasarkan Status Stunting

\begin{tabular}{|c|c|c|c|c|c|c|}
\hline \multirow{2}{*}{ Peubah } & \multicolumn{3}{|c|}{$0-5$ bulan $(n=229)$} & \multicolumn{3}{|c|}{$6-11$ bulan $(n=695)$} \\
\hline & Stunting & Non-stunting & Total & Stunting & Non-stunting & Total \\
\hline Jml. jen is, jenis & $1.3 \pm 0.6$ & $1.3 \pm 0.6$ & $1.3 \pm 0.6$ & $3.1 \pm 1.6$ & $3.2 \pm 1.5$ & $3.2 \pm 1.5$ \\
\hline Jml. kelompok, kelompok & $1.2 \pm 0.4$ & $1.2 \pm 0.5$ & $1.2 \pm 0.5$ & $2.2 \pm 0.8$ & $2.2 \pm 0.8$ & $2.2 \pm 0.8$ \\
\hline Frekuensi, kali & $2.8 \pm 1.4$ & $2.6 \pm 1.5$ & $2.6 \pm 1.5$ & $3.3 \pm 0.8$ & $3.3 \pm 0.8$ & $3.3 \pm 0.8$ \\
\hline Tk. energi, \% & $77.5 \pm 43.5$ & $72.1 \pm 30.5$ & $73.4 \pm 34.1$ & $69.8 \pm 34.2$ & $71.9 \pm 34.2$ & $71.2 \pm 34.2$ \\
\hline Tk. protein, $\%$ & $70.8 \pm 28.3$ & $70.4 \pm 25.5$ & $70.5 \pm 26.1$ & $80.2 \pm 48.9$ & $93.2 \pm 58.2$ & $88.9 \pm 55.8^{* *}$ \\
\hline Da. protein, $\mathrm{g} / 1000 \mathrm{kkal}$ & $19.6 \pm 8.0$ & $18.9 \pm 6.6$ & $19.0 \pm 6.9$ & $25.2 \pm 11.4$ & $28.1 \pm 13.8$ & $27.2 \pm 13.1^{* *}$ \\
\hline Tk. kalsium, \% & $109.4 \pm 45.3$ & $109.3 \pm 45.3$ & $109.3 \pm 45.2$ & $62.3 \pm 56.4$ & $63.9 \pm 60.4$ & $63.4 \pm 59.1$ \\
\hline Da. kalsium, $\mathrm{mg} / 1000 \mathrm{kkal}$ & $598.3 \pm 293.1$ & $583.4 \pm 271.2$ & $587.0 \pm 276.2$ & $508.9 \pm 473.8$ & $518.5 \pm 504.2$ & $515.3 \pm 494.1$ \\
\hline Tk. fosfor, \% & $90.5 \pm 53.0$ & $90.6 \pm 54.7$ & $90.6 \pm 54.2$ & $92.8 \pm 77.2$ & $100.6 \pm 76.7$ & $98.0 \pm 76.9$ \\
\hline Tk. zat besi, $\%$ & $15.4 \pm 31.6$ & $16.4 \pm 30.3$ & $16.1 \pm 30.5$ & $24.0 \pm 27.1$ & $25.0 \pm 24.7$ & $24.6 \pm 25.5$ \\
\hline Da. zat besi, $\mathrm{mg} / 1000 \mathrm{kkal}$ & $0.3 \pm 0.8$ & $0.3 \pm 0.6$ & $0.3 \pm 0.7$ & $3.1 \pm 3.0$ & $3.1 \pm 2.6$ & $3.1 \pm 2.8$ \\
\hline Tk. vit. A, \% & $105.8 \pm 45.9$ & $105.8 \pm 44.7$ & $105.8 \pm 44.9$ & $74.1 \pm 58.9$ & $75.1 \pm 63.1$ & $74.8 \pm 61.7$ \\
\hline Da. vit. A, mg/ $1000 \mathrm{kkal}$ & $1019 \pm 198$ & $1002 \pm 193$ & $1006 \pm 194$ & $629 \pm 440$ & $604 \pm 448$ & $612 \pm 445$ \\
\hline Tk. vit. B1,\% & $382.9 \pm 167.6$ & $388.9 \pm 165.8$ & $387.4 \pm 165.9$ & $247.7 \pm 167.0$ & $244.8 \pm 169.0$ & $245.8 \pm 168.2$ \\
\hline Da. vit. B1, $\mu \mathrm{g} / 1000 \mathrm{kkal}$ & $3.0 \pm 0.7$ & $3.0 \pm 0.7$ & $3.0 \pm 0.7$ & $2.3 \pm 1.5$ & $2.1 \pm 1.4$ & $2.2 \pm 1.4$ \\
\hline Tk. vit. C, \% & $37.4 \pm 17.6$ & $37.3 \pm 17.3$ & $37.3 \pm 17.3$ & $26.2 \pm 25.5$ & $25.2 \pm 26.9$ & $25.5 \pm 26.4$ \\
\hline Da. vit. C, $\mathrm{mg} / 1000 \mathrm{kkal}$ & $37.6 \pm 9.2$ & $37.0 \pm 10.0$ & $37.1 \pm 9.8$ & $23.3 \pm 24.8$ & $20.7 \pm 21.7$ & $21.6 \pm 22.8$ \\
\hline Mutu gizi asupan pangan & $68.1 \pm 15.1$ & $68.4 \pm 15.0$ & $68.3 \pm 15.0$ & $56.1 \pm 21.7$ & $57.3 \pm 20.4$ & $56.9 \pm 20.8$ \\
\hline
\end{tabular}

Tabel 2. Pola Konsumsi, Asupan Energi, dan Zat Gizi Harian Anak 0-23 Bulan berdasarkan Status Stunting (lanjutan)

\begin{tabular}{|c|c|c|c|c|c|c|}
\hline \multirow{2}{*}{ Peubah } & \multicolumn{3}{|c|}{$12-23$ bulan $(n=2171)$} & \multicolumn{3}{|c|}{$0-23$ bulan $(n=3$ 095) } \\
\hline & Stunting & Non-stunting & Total & Stunting & Non-stunting & Total \\
\hline Jml. jenis, jenis & $4.4 \pm 1.9$ & $4.6 \pm 2.0$ & $4.6 \pm 2.0^{*}$ & $4.0 \pm 2.0$ & $4.0 \pm 2.1$ & $4.0 \pm 2.1$ \\
\hline Jml. kelompok, kelompok & $2.8 \pm 0.9$ & $2.8 \pm 0.9$ & $2.8 \pm 0.9$ & $2.6 \pm 1.0$ & $2.5 \pm 1.0$ & $2.6 \pm 1.0$ \\
\hline Frekuensi, kali & $3.4 \pm 0.7$ & $3.5 \pm 0.6$ & $3.5 \pm 0.7$ & $3.4 \pm 0.8$ & $3.4 \pm 0.8$ & $3.4 \pm 0.8$ \\
\hline Tk. energi, \% & $82.3 \pm 37.7$ & $85.9 \pm 38.6$ & $84.4 \pm 38.3^{*}$ & $79.6 \pm 37.6$ & $81.3 \pm 37.4$ & $80.7 \pm 37.5$ \\
\hline Tk. protein, $\%$ & $150.2 \pm 88.8$ & $161.1 \pm 89.8$ & $156.7 \pm 89.5^{* *}$ & $132.6 \pm 86.1$ & $136.7 \pm 86.7$ & $135.1 \pm 86.5$ \\
\hline Da. protein, g/ $1000 \mathrm{kkal}$ & $29.4 \pm 13.2$ & $30.8 \pm 13.5$ & $30.3 \pm 13.4^{* *}$ & $29.6 \pm 19.3$ & $30.2 \pm 19.3$ & $30.0 \pm 19.3$ \\
\hline Tk. kalsium, \% & $57.9 \pm 58.2$ & $65.9 \pm 63.4$ & $62.7 \pm 61.5^{* *}$ & $61.2 \pm 58.3$ & $69.3 \pm 62.5$ & $66.3 \pm 61.1^{* *}$ \\
\hline Da. kalsium, mg / $1000 \mathrm{kkal}$ & $405.7 \pm 406.2$ & $440.3 \pm 420.3$ & $426.4 \pm 414.9^{*}$ & $435.4 \pm 419.1$ & $471.9 \pm 433.9$ & $458.3 \pm 428.7^{*}$ \\
\hline Tk. fosfor, \% & $82.6 \pm 63.6$ & $92.3 \pm 66.3$ & $88.4 \pm 65.4^{* *}$ & $85.0 \pm 66.2$ & $94.2 \pm 68.1$ & $90.7 \pm 67.5^{* *}$ \\
\hline Tk. zat besi, $\%$ & $42.0 \pm 29.8$ & $43.8 \pm 29.8$ & $43.0 \pm 29.8$ & $37.1 \pm 30.6$ & $36.8 \pm 30.4$ & $36.9 \pm 30.5$ \\
\hline Da. zat besi, mg / $1000 \mathrm{kkal}$ & $4.7 \pm 3.2$ & $4.6 \pm 3.0$ & $4.6 \pm 3.1$ & $4.1 \pm 3.2$ & $3.9 \pm 3.1$ & $4.0 \pm 3.1^{*}$ \\
\hline Tk. vit. A, \% & $79.6 \pm 67.3$ & $86.5 \pm 70.1$ & $83.7 \pm 69.0^{*}$ & $79.8 \pm 65.1$ & $85.5 \pm 67.0$ & $83.3 \pm 66.3^{*}$ \\
\hline Da. vit. A, mg/ $1000 \mathrm{kkal}$ & $462 \pm 413$ & $479 \pm 393$ & $472 \pm 401$ & $522 \pm 431$ & $556 \pm 421$ & $543 \pm 425^{* *}$ \\
\hline Tk. vit. B1, \% & $155.0 \pm 138.8$ & $155.2 \pm 134.5$ & $155.1 \pm 136.2$ & $184.3 \pm 157.1$ & $197.6 \pm 162.6$ & $192.7 \pm 160.7^{*}$ \\
\hline Da. vit. B1, $\mu \mathrm{g} / 1000 \mathrm{kkal}$ & $1.2 \pm 1.1$ & $1.1 \pm 1.0$ & $1.1 \pm 1.1$ & $1.5 \pm 1.3$ & $1.5 \pm 1.3$ & $1.5 \pm 1.3$ \\
\hline Tk. vit. C, \% & $25.0 \pm 26.5$ & $27.2 \pm 27.6$ & $26.3 \pm 27.2^{*}$ & $25.8 \pm 26.0$ & $27.6 \pm 26.9$ & $27.0 \pm 26.6$ \\
\hline Da. vit. C, mg/ $1000 \mathrm{kkal}$ & $15.4 \pm 19.0$ & $15.7 \pm 17.4$ & $15.6 \pm 18.1$ & $18.0 \pm 20.7$ & $18.8 \pm 19.0$ & $18.5 \pm 19.7^{*}$ \\
\hline Mutu gizi asupan pangan & $59.0 \pm 20.9$ & $61.9 \pm 20.2$ & $60.7 \pm 20.5^{* *}$ & $58.9 \pm 20.9$ & $61.3 \pm 20.0$ & $60.4 \pm 20.4^{* *}$ \\
\hline
\end{tabular}

Tabel 3. Sebaran Anak berdasarkan Status Stunting dan Jumlah Jenis Pangan Harian yang Dikonsumsi anak 0-23 Bulan (\%)

\begin{tabular}{lcc}
\hline $\begin{array}{c}\text { Jumlah Jenis } \\
\text { Pangan }\end{array}$ & $\begin{array}{c}\text { Stunting } \\
(\mathbf{n}=\mathbf{1 1 5 6 )}\end{array}$ & $\begin{array}{c}\text { Tidak stunting } \\
(\mathbf{n}=1 \text { 939) }\end{array}$ \\
\hline Satu jenis & 32.2 & 67.8 \\
Dua jenis & 39.3 & 60.7 \\
Tiga jenis & 36.1 & 63.9 \\
Empat jenis & 38.8 & 61.2 \\
Lima jenis & 40.3 & 59.7 \\
Enam jen is & 35.3 & 64.7 \\
Tujuh jenis & 43.3 & 56.7 \\
Delapan jenis & 31.5 & 68.5 \\
Sembilan jenis & 39.1 & 60.9 \\
Sepuluh jenis & 20.0 & 80.0 \\
Sebelas jenis & 9.1 & 90.9 \\
Dua belas jenis & 33.3 & 66.7 \\
Tiga belas jenis & 100.0 & 0 \\
Total & 37.4 & 62.6 \\
\hline
\end{tabular}

pan, mencakup padi-padian, umbi-umbian, hewani, minyak atau lemak, kacang-kacangan, buah/biji berminyak, gula, dan sayur/buah. Pangan hewani dan sayur/buah lebih banyak dikonsumsi dibanding kelompok pangan lain, dan jumlah kedua kelompok pangan cenderung lebih sedikit dikonsumsi anak stunting dibanding anak tidak stunting (Tabel 4).

Rata-rata jumlah kelompok pangan yang dikonsumsi anak stunting $0-5,6-11$, dan 12-23 bulan sama dengan anak tidak stunting $(p \geq 0.05)$. Bertambah usia bertambah pula jumlah kelompok pangan yang dikonsumsi anak 0-23 bulan. Rata-rata jumlah kelompok pangan yang dikonsumsi anak $0-5,6-11$, dan $12-23$ bulan berturut-turut yaitu $1.2 \pm 0.5,2.2 \pm 0.8$, dan $2.8 \pm 0.9$ kelompok per hari.

\section{Frekuensi Konsumsi Pangan}

Rata-rata frekuensi konsumsi pangan harian anak $0-5,6-11$, dan $12-23$ stunting sama dengan anak tidak stunting $(p>0.05)$. Bertambah usia bertambah pula frekuensi konsumsi pangan anak 0-23 bulan. Rata-rata frekuensi konsumsi pangan anak $0-5$, 6-11, dan 12-23 bulan berturut-turut yaitu 
Tabel 4. Jumlah Jenis Pangan berdasarkan Kelompok Pangan yang Dikonsumsi Anak 0-23 Bulan

\begin{tabular}{lccc}
\hline \multicolumn{1}{c}{ Kelompok Pangan } & Stunting & $\begin{array}{c}\text { Tidak } \\
\text { stunting }\end{array}$ & Total \\
\hline Padi-padian, jenis & 31 & 35 & 37 \\
Umbi-umbian, jenis & 9 & 11 & 13 \\
Hewani, jenis & 49 & 52 & 57 \\
Minyak/lemak ${ }^{*}$, jenis & 0 & 0 & 0 \\
Kacang-kacangan, jenis & 12 & 12 & 14 \\
Buah/bijiberminyak ${ }^{\ddagger}$, jenis & 2 & 2 & 2 \\
Gula, jenis & 4 & 6 & 6 \\
Sayur/buah, jenis & 54 & 71 & 74 \\
\hline Total & 161 & 189 & 203 \\
\hline
\end{tabular}

Keterangan: * mentega, margarin; ‡ kelapa, santan

$2.6 \pm 1.5,3.3 \pm 0.8$, dan $3.5 \pm 0.7$ kelompok per hari. Mereka rata-rata mengonsumsi pangan 3.4 kali per hari. Hal ini sama dengan kesimpulan Hoppe et al. (2004) yaitu selama periode pemberian makanan tambahan, asupan harian anak sebanyak 3-4 kali memberikan pengaruh paling baik terhadap pertumbuhan (Tabel 5).

Tabel 5. Sebaran Anak berdasarkan Status Stunting dan Frekuensi Konsumsi Pangan Harian Anak 0-23 Bulan

\begin{tabular}{lcccc}
\hline \multirow{2}{*}{ Frekuensi } & \multicolumn{2}{c}{ Stunting } & \multicolumn{2}{c}{ Tidak stunting } \\
\cline { 2 - 5 } Konsumsi Pangan & $\mathbf{n}$ & $\%$ & $\mathrm{n}$ & $\%$ \\
\hline Satu kali & 37 & 31.4 & 81 & 68.6 \\
Dua kali & 45 & 40.5 & 66 & 59.5 \\
Tiga kali & 489 & 37.6 & 811 & 62.4 \\
Empat kali & 585 & 37.4 & 981 & 62.6 \\
\hline Total & 1156 & 37.4 & 1939 & 62.6 \\
\hline
\end{tabular}

\section{Asupan Energi dan Zat Gizi}

Rata-rata asupan energi dan zat gizi anak stunting sama dengan anak tidak stunting $0-5$ bulan, namun berbeda pada anak 6-11 dan 12-23 bulan. Hal ini sejalan dengan kesimpulan (Hayati et al. 2012) bahwa risiko stunting anak 6-11 bulan 1.52 kali anak $0-5$ bulan $(\mathrm{p}<0.05)$, dan peluang stunting anak $12-23$ bulan 2.04 kali anak $0-5$ bulan $(p<0.01)$.

Pada anak 0-5 bulan, rata-rata tingkat kecukupan zat gizi, densitas asupan zat gizi, maupun mutu gizi asupan pangan anak stunting sama dengan anak tidak stunting. Hal ini antara lain karena pada usia tersebut ASI saja sudah cukup untuk memenuhi kebutuhan gizi mereka. WHO menganjurkan bahwa anak usia $0-5$ bulan agar hanya diberikan ASI saja sedangkan Winarno (1990) menjelaskan pula bahwa selama 4-6 bulan pertama, ASI mampu memenuhi kebutuhan gizi bayi.

Pada usia anak 6-11 bulan, tingkat kecukupan protein anak stunting dan tidak stunting berbeda, demikian pula densitas asupan protein. Rata-rata tingkat kecukupan protein anak stunting dan anak tidak stunting $6-11$ bulan berturut-turut $80.2 \pm 48.9$ dan $93.2 \pm 58.2 \%(p<0.01)$; dan densitas asupan pro- tein anak stunting dan anak tidak stunting 6-11 bulan berturut-turut $25.2 \pm 11.4$ dan $28.1 \pm 13.8$ g per $1000 \mathrm{kkal}(\mathrm{p}<0.01)$. Rata-rata asupan protein anak stunting lebih sedikit dibanding anak tidak stunting. Hal ini mendukung penjelasan Winarno (1990) yaitu setelah 6 bulan, volume pengeluaran ASI menjadi menurun dan sejak saat itu kebutuhan zat gizi bayi tidak lagi dapat dipenuhi oleh ASI saja dan harus mendapat makanan tambahan. WHO (2001) juga menganjurkan bahwa anak usia 6-11 bulan, disamping ASI juga diberikan makanan pendamping ASI (MP-ASI) sehingga anak mulai mengonsumsi makanan dan/atau minuman selain ASI.

Pada anak 12-23 bulan, tidak hanya rata-rata tingkat kecukupan protein dan densitas asupan protein, tetapi rata-rata tingkat kecukupan energi, tingkat kecukupan kalsium dan densitas asupan kalsium, tingkat kecukupan fosfor, tingkat kecukupan vitamin $A$, tingkat kecukupan vitamin $C$ juga berbeda; yang tidak berbeda pada anak $12-23$ bulan antara anak stunting dan anak tidak stunting hanya tingkat asupan dan densitas asupan zat besi serta tingkat asupan dan densitas asupan vitamin B1. Tingkat asupan zat besi tidak berbeda antara anak stunting dan anak tidak stunting $12-23$ bulan, namun tingkat konsumsinya rendah yaitu hanya $43.0 \pm 29.8 \%$. Kemenkes (2010) melaporkan bahwa kebutuhan minimal zat besi yaitu 50\%. Adapun tingkat asupan vitamin B1 tidak berbeda antara anak stunting dan anak stunting 12-23 bulan antara lain disebabkan sumber energi utama berasal dari serealia yang kaya kandungan vitamin B1. Selain itu, secara nasional vitamin B1 tidak termasuk masalah gizi. Namun demikian, mutu gizi makanan anak stunting dan anak tidak stunting 12-23 bulan berbeda $(p<0.01)$. Rata-rata mutu gizi makanan anak stunting dan tidak stunting berturut-turut yaitu $59.0 \pm 20.9$ dan $61.9 \pm 20.2$. Hardinsyah (2001) menjelaskan bahwa mutu gizi asupan pangan tergolong cukup apabila $\geq 70 \%$. WHO (2001) melaporkan salah satu penyebab stunting adalah ASI, serta kualitas dan kuantitas makanan pendamping ASI yang tidak adequate. WHO juga menganjurkan mulai usia 12 bulan, anak diperkenalkan makanan orang dewasa dengan memperhatikan tekstur dan rasa yang sesuai, dan dibutuhkan perubahan secara bertahap dari makanan lembut ke makanan keluarga. Di sisi lain, Drewnowski (2003) menyimpulkan bahwa protein, kalsium, zat besi, serta vitamin A dan C merupakan zat kunci yang perlu diberikan untuk menolong kelompok berpendapatan rendah. Hayati et al. (2012) menyimpulkan bahwa risiko stunting anak dengan status ekonomi keluarga bawah kuintil (1\&2) sebesar 1.28 kali dibanding dengan status ekonomi menengah atas $(p<0.01)$.

Pada anak 0-23 bulan secara keseluruhan, pola konsumsi pangan, asupan energi dan zat gizi anak stunting dan tidak stunting 0-23 bulan sama, 
kecuali zat gizi mikro. Tidak ada perbedaan ratarata jumlah jenis konsumsi pangan, jumlah kelompok konsumsi pangan, jumlah frekuensi konsumsi pangan, dan tingkat kecukupan energi dan protein, dan densitas asupan protein antara anak stunting dan tidak stunting, namun demikian terdapat perbedaan rata-rata tingkat kecukupan dan/atau densitas zat gizi mikro. Rata-rata tingkat kecukupan energi, tingkat kecukupan protein, dan densitas asupan protein anak berturut-turut yaitu $80.7 \pm 37.5 \%$, $135.1 \pm 86.5 \%$, dan $30.0 \pm 19.3 \mathrm{~g} / 1000 \mathrm{kkal}$. Adapun rata-rata asupan zat gizi mikro anak stunting yang meliputi tingkat kecukupan dan/densitas kalsium, fosfor, zat besi, vitamin A, vitamin B1, dan vitamin $C$ berbeda dengan anak tidak stunting. Tingkat kecukupan dan densitas kalsium anak stunting lebih rendah dibanding anak tidak stunting, begitu juga dengan tingkat kecukupan fosfor, tingkat kecukupan dan densitas vitamin A, tingkat kecukupan vitamin B1, dan densitas asupan vitamin C, namun demikian densitas asupan zat besi anak stunting lebih tinggi dibanding anak tidak stunting.

Uji Mann-Whitney $U$ menunjukkan bahwa ada perbedaan rata-rata densitas asupan zat besi anak 0-23 bulan stunting dan anak tidak stunting $(p<0.05)$, namun tingkat kecukupan zat besi tidak berbeda $(p \geq 0.05)$; begitu juga dengan vitamin $C$ 0-23 bulan. Hal ini menunjukkan bahwa densitas zat besi maupun vitamin $C$ lebih sensitif untuk dapat membedakan asupan anak stunting dan anak tidak stunting dibandingkan dengan tingkat kecukupan zat besi maupun vitamin C. Sebaliknya dengan asupan vitamin B1, yaitu tingkat kecukupan vitamin B1 lebih sensitif untuk dapat membedakan asupan anak stunting dan anak tidak stunting $(p<0.05)$ dibandingkan dengan densitas asupan vitamin B1 ( $p>0.05)$. Dengan demikian, untuk membedakan asupan gizi anak stunting dan anak tidak stunting dapat menggunakan tingkat kecukupan gizi dan/ atau densitas asupan gizi, dengan ketentuan minimal salah satu dari kedua peubah asupan gizi tersebut tingkat kecukupan dan/atau densitas asupan gizi hasil uji statistiknya menunjukkan perbedaan antara anak stunting dan anak tidak stunting.

Pada anak 0-5 bulan, belum ada masalah asupan energi dan zat gizi. Namun, pada anak 6-12 bulan mulai muncul masalah asupan protein. Pada anak 12-23 bulan, masalah bertambah yaitu menjadi zat gizi makro (energi \& protein), dan zat mikro kalsium, fosfor, vitamin A, dan vitamin C. Terlihat bahwa masalah asupan protein merupakan gejala awal munculnya masalah gizi yang terkait dengan pertumbuhan linier anak 0-23 bulan. Dari uraian tersebut dapat dilihat bahwa protein merupakan gejala awal perbedaan konsumsi zat gizi yang terkait dengan pertumbuhan linier anak 0-23 bulan.

\section{Pola Konsumsi Pangan, Asupan Energi dan Zat Gizi}

Uji Mann-Whitney U menunjukkan bahwa pola konsumsi pangan, asupan energi dan zat gizi anak stunting dan tidak stunting 0-23 bulan berbeda menurut kelompok umur. Semakin bertambah umur, semakin meningkat perbedaan tersebut. Dari tiga komponen pola konsumsi pangan dan asupan energi dan gizi meliputi jumlah jenis/kelompok konsumsi pangan, frekuensi konsumsi pangan, dan asupan energi dan gizi, tidak ada yang berbeda pada anak 0-5 bulan anak stunting dan tidak stunting; sebaliknya pada anak 6-11 bulan, berbeda satu peubah yakni asupan zat gizi; pada anak 12-23 bulan, semakin bertambah perbedaan tersebut yakni selain asupan zat gizi, jumlah jenis konsumsi pangan juga berbeda.

Pola konsumsi pangan, asupan energi dan zat gizi anak stunting dan tidak stunting 0-23 bulan sama, kecuali zat gizi mikro. Uji Mann-Whitney $U$ menunjukkan bahwa tidak ada perbedaan rata-rata jumlah jenis/kelompok konsumsi pangan, jumlah frekuensi konsumsi pangan, dan tingkat kecukupan dan/atau densitas asupan zat gizi makro (energi \& protein), antara anak stunting dan tidak stunting, namun ada perbedaan rata-rata tingkat kecukupan dan/atau densitas asupan zat gizi mikro. Frongillo (1999) menyimpulkan bahwa salah satu penyebab penurunan pertumbuhan linier adalah kekurangan zat gizi mikro (multivitamin mineral). Sumber mineral dan vitamin terbaik untuk bayi berasal dari pangan hewani, meliputi daging sapi, jeroan, daging unggas, ikan, kerang, telur, serta susu dan hasil olahannya. WHO (1998) menjelaskan bahwa makanan yang kaya protein mengandung mineral dan vitamin yang tinggi, misalnya kalsium, zat besi, vitamin A, dan vitamin B12. Hoppe et al. (2004) menyimpulkan bahwa asupan protein pada anak 9 bulan dihubungkan dengan ukuran tubuh. Hayati et al. (2012) menyimpulkan bahwa densitas asupan protein merupakan salah satu faktor determinan anak stunting 0-23 bulan di Indonesia. Sebanyak 38.1\% anak 0-23 bulan yang mengonsumsi pangan dengan densitas asupan protein rendah mengalami stunting. Risiko stunting anak 0-23 bulan dengan densitas asupan protein rendah (<40 g per $1000 \mathrm{kkal}$ ) sebesar 1.22 kali dibanding dengan anak yang densitas asupan proteinnya tidak rendah $(p<0.05)$. Adapun densitas asupan protein anak 0-23 bulan yang stunting dan 
yang tidak stunting berturut-turut $29.6 \mathrm{~g}$ dan 30.2 per $1000 \mathrm{kkal}$.

Jumlah konsumsi ASI anak 6-23 bulan belum mencukupi kebutuhan. Jumlah anak 0-23 bulan yang pernah diberi ASI sebanyak 90.2\%, sebanyak 3.05\% diantaranya merupakan ASI eksklusif tidak berbeda antara anak (stunting dan tidak stunting). Jumlah asupan ASI anak 0-5 bulan sebanyak 591.6 g/hari (Tabel 6).

Tabel 6. Jumlah Asupan ASI Harian Anak 0-23 Bulan

\begin{tabular}{cccc}
\hline $\begin{array}{c}\text { Umur } \\
\text { (Bulan) }\end{array}$ & $\begin{array}{c}\text { Jumlah } \\
\text { (g/kali konsumsi) }\end{array}$ & $\begin{array}{c}\text { Frekuensi } \\
\text { (Kali) }\end{array}$ & $\begin{array}{c}\text { Total } \\
\text { (g) }\end{array}$ \\
\hline $0-5$ & 144.3 & 4.1 & 591.6 \\
$6-11$ & 142.4 & 3.5 & 498.4 \\
$12-23$ & 150.4 & 3.1 & 466.2 \\
\hline
\end{tabular}

Hal ini sejalan dengan penelitian Simondon et al. (1996) yaitu rata-rata asupan ASI anak 4-5 bulan di Brazzaville sebanyak $460 \mathrm{~g} /$ hari pada bayi yang tidak mengonsumsi susu formula. Adapun jumlah asupan ASI anak 6-11 bulan sebanyak $498.4 \mathrm{~g} /$ hari. Jumlah ini hampir sama dengan yang dilaporkan WHO (1998) yaitu konsumsi ASI anak 6-8 bulan di negara berkembang sebanyak $328.8 \mathrm{~g} / \mathrm{hari}$. Bhadam dan Sweet (2010) menyimpulkan bahwa walaupun menyusu dengan optimal, anak akan menjadi stunting jika tidak menerima MP-ASI dalam jumlah dan kualitas yang cukup setelah berusia enam bulan. Dietitians of Canada (2012) menjelaskan bahwa orang-orang yang mengonsumsi susu kurang dari 500 $\mathrm{ml}$ (2 gelas) per hari membutuhkan suplemen mineral dan vitamin.

Suplemen zat gizi mikro mengurangi hambatan pertumbuhan linier anak 0-23 bulan, namun belum optimal. WHO (1998) menjelaskan bahwa penelitian longitudinal yang dilakukan oleh INCAP/Institute of Nutrition of Central America and Panama di Panama, tentang ibu dan bayi (umumnya dari usia empat bulan) yang diberi suplemen zat gizi mikro maka, suplemen tersebut mengurangi hambatan pertumbuhan pada 2-3 tahun pertama kehidupan, namun bayi dan anak masih tetap stunting berat. WHO (2001) melaporkan bahwa berdasarkan review dari 23 kombinasi MP-ASI yang digunakan di negara berkembang, meliputi beberapa produk hewani, mengungkapkan bahwa meskipun sebagian besar dari mereka dapat menyediakan energi dan protein yang cukup, namun tidak ada yang menyediakan mineral dan vitamin yang cukup. Ramakrishnan et al. (2009) menyimpulkan dari studi meta-analisis intervensi zat gizi mikro (mengandung setidaknya tiga/lebih zat gizi mikro) bahwa mereka dapat meningkatkan pertumbuhan linear, tapi manfaatnya kecil, sehingga diperlukan penelitian suplemen yang mengandung beberapa zat gizi mikro yang memiliki dampak lebih besar terhadap pencapaian pertumbuhan linier optimal anak 0-23 bulan.

\section{KESIMPULAN}

Pola konsumsi pangan dan asupan energi dan gizi anak stunting dan tidak stunting 0-23 bulan berbeda menurut kelompok umur; semakin bertambah umur semakin meningkat perbedaannya. Pada anak 0-5 bulan tidak ada perbedaan pola konsumsi pangan dan asupan energi dan gizi anak stunting dan tidak stunting; sebaliknya pada anak 6-11 dan 12-23 bulan. Pada anak 6-11 bulan, rata-rata tingkat kecukupan protein anak stunting dan tidak stunting berbeda, demikian pula densitas asupan protein. Pada anak 12-23 bulan, tidak hanya ratarata tingkat kecukupan protein dan densitas asupan protein, tetapi rata-rata tingkat kecukupan energi, tingkat kecukupan kalsium dan densitas asupan kalsium, tingkat kecukupan fosfor, tingkat kecukupan vitamin A, tingkat kecukupan vitamin $C$, mutu gizi makanan, dan bahkan jenis pangan juga berbeda.

Pencegahan stunting anak 0-23 bulan perlu dilakukan dengan meningkatkan kualitas MP-ASI. Perlu dilakukan penelitian efikasi intervensi zat gizi tersebut di atas untuk pencapaian pertumbuhan linier optimal anak.

\section{UCAPAN TERIMA KASIH}

Peneliti mengucapkan terimakasih kepada Balitbangkes Kemenkes yang telah mengijinkan penggunaan data penelitian ini.

\section{DAFTAR PUSTAKA}

Amilia L. 2011. Analisis Asupan Air dan Mutu Gizi Asupan Pangan pada Anak di Indonesia [skripsi]. Fakultas Ekologi Manusia, IPB, Bogor.

Bhadam J \& Sweet L. 2010. Stunting: An Overview. Sight and Life Magazine, 3, 40-47.

Bhutta ZA et al. 2008. What works? Interventions for maternal and child undernutrition and survival. Lancet, 371, 417-40.

Blössner M, Siyam A, Borghi E, Onyango A, \& Onis M. 2009. WHO AnthroPlus for Personal Computers Manual. WHO, Geneva.

Dietitians of Canada. 2012. Do I need a vitamin or mineral supplement?. http://www.dietitians. $\mathrm{ca} /$ Nutrition-Resources-A-Z/Factsheets/Miscellane-ous/Do-I-Need-a-Supplement-.aspx [9 Nopember 2012].

Drewnowski A. 2005. Concept of a nutritious food: toward a nutrient density score. Am J Clin Nutr, 79, 6-16.

Frongillo EA. 1999. Symposium: causes and etiology of stunting. Nutr, 129, 529S-530S.

Hayati AW, Hardinsyah, Jalal F, Madanijah S, \& Briawan D. Determinan Stunting Anak Baduta: Analisis Data Riskesdas 2010. Di dalam: Ketahanan Pangan dan Gizi di Era Otonomi Dae- 
rah dan Globalisasi Pemantapan Ketahanan Pangan dan Perbaikan Gizi Berbasis Kemandirian dan Kearifan Lokal. Prosiding Widyakarya Nasional Pangan dan Gizi X. 2012. Jakarta, 20-21 Nopember 2012. LIPI, Bappenas, Kementan, Kemenkes, Badan POM, Ristek, Jakarta.

Hardinsyah \& Briawan D. 1994. Assesment and Planning of Food Consumption. Community Nutrition and Family Resources Department. Bogor Agricultural University, Bogor.

Hardinsyah. 2001. Mutu Gizi dan Konsumsi Pangan. Di dalam: Hardinsyah, Atmojo SM, editor. Pengendalian Mutu dan Keamanan Pangan. Pergizi Pangan, Jakarta.

Hoppe C, Molgaard C, Thomsen L, Juul A, \& Michalsen KF. 2004. Protein intake at 9 mo of age is associated with body size but not with body fat in 10-y-od Danish children. Am J Clin, 79, 494-501.

Jahari AB. 2009. Growth Curve of Healthy Children from Wealthy Families: How Close to WHO Child Growth Standard 2005? Center for Research and Development in Food and Nutrition National Institute for Health Research and Development, Ministry of Health of RI, Bogor.

[Kemenkes] Kementerian Kesehatan. 2010. Survey Kesehatan Nasional. Kemenkes, Jakarta.

Kusharisupeni. 2006. Peran status kelahiran terhadap stunting pada bayi: sebuah studi prospektif. J Kedokter Trisakti, (233), 73-80.

Mahan K, Escott-Stump. 2008. Food, Nutrition, and Diet Therapy. W.B Saunders Company, USA.
Ramakrishnan U, Nguyen P, \& Martorel R. 2009. Effects of micronutrients on growth of children under 5 years of age: meta-analyses of single and multiple interventions. Am J Clin Nutr, 89, 191-203.

Simondon KB, Gartner A, Berger J, Cornii A, Massamba J, Miguel JS, Ly C, Missotte I, Sisimondon F, Traissac P, Delpeuch F, \& Maire B. 1996. Effect of early, short-term supplementation on weight and linear growth of 4-7-mo-old infants in developing countries: a four-country randomized trial. Am J Clin Nutr, 64, 537-45.

Ulfani DH, Martianto1 D, \& Baliwati YF. 2011. Faktor-faktor sosial ekonomi dan kesehatan masyarakat kaitannya dengan masalah gizi underweight, stunted, dan wasted di Indonesia: Pendekatan ekologi gizi. Jurnal Gizi dan Pangan, 6(1), 59-65.

Winarno FG. 1990. Gizi dan Makanan bagi Bayi dan Anak Sapihan. Sinar Harapan, Jakarta.

[WHO] World Health Organization. 1998. Preparation and Use of Food Based Dietary Guidelines. WHO, Geneva.

[WHO] World Health Organization. 2001. Improving Child Growth. WHO, Geneva.

[WHO] World Health Organization. 2006. Table of Standard Anthropometry WHO-2005. WHO, Geneva.

[WNPG] Widyakarya Nasional Pangan dan Gizi VIII. Ketahanan Pangan dan Gizi di Era Otonomi Daerah dan Globalisasi. Jakarta, 17-19 Mei 2004. 